Annals of Warsaw University of Life Sciences - SGGW

Land Reclamation No 49 (4), 2017: 277-287

(Ann. Warsaw Univ. of Life Sci. - SGGW, Land Reclam. 49 (4), 2017)

\title{
Restoration of Cnidion dubii meadows on Warsaw cross-section of the Middle Vistula Valley
}

\author{
BOGUMIŁA PAWLUŚKIEWICZ ${ }^{1}$, MARIA JANICKA ${ }^{2}$, KAZIMIERZ PIEKUT ${ }^{1}$ \\ ${ }^{1}$ Faculty of Civil and Environmental Engineering \\ ${ }^{2}$ Faculty of Agriculture and Biology \\ Warsaw University of Life Sciences - SGGW
}

\begin{abstract}
Restoration of Cnidion dubii meadows on Warsaw cross-section of the Middle Vistula Valley. The studies were carried out as the part of flooded meadows' restoration on the Warsaw cross-section of Natura 2000 site Middle Vistula Valley. They concerned determination the possibility of restoration and improvement of species composition plant communities of meadows in river valleys by limitation growth of the invasive alien species and introducing diasporas of plant species from natural meadows. Seeding material for restoration was taken from well preserved natural Cnidion dubii meadows lying in Lower Pilica Valley in the neighborhood of Warsaw. Seeding material contained 26 native species including representative species for Cnidion dubii meadows: Cnidium dubium, Allium angulosum, Sanguisorba officinalis and Galium boreale. Three levels of seedbed preparation intensity were checked: low cutting of old vegetation; ploughing on depth about $20 \mathrm{~cm}$ and rototilling, removing of sward and upper soil layer thick $30 \mathrm{~cm}$. Two ways of seeding material placement were also tested: sowing + rolling + mulching (covering with straw); sowing + rolling (without mulching). The applied methods of seedbed preparation and used seeding material allowed introducing of 17 plant species. Removing of topsoil was the most effective in limitation of invasive alien species occurrence and favored emergence and initial growth of Sanguisorba officinalis, Allium angulosum and Galium boreale. Ploughing and rototilling of topsoil layer effectively limited of Acer negundo occurrence and favored the growth of Cnidium dubium.
\end{abstract}

Key words: Middle Vistula Valley, flooded meadows' restoration, sowing of target species

\section{INTRODUCTION}

The necessity of restraining the biodiversity lost in the EU is being underlined in the EU Biodiversity Strategy 2020 (European Commission 2011). The significant pieces of this law which strengthening of the natural resources and ecosystem services preservation is Environmental Liability Directive 2004/35/EC. Together with the Habitat Directive (1992) and the Birds (2009) Directive they create the responsibilities system for biodiversity harms preventing. Regulations of these system stated, that persons whose activities directly threat the environment are also responsible for undertaking preventive actions (Ballesteros et al. 2014).

The loss of the native meadows flora is still progressing in the European Union countries, especially species-rich floodplain meadows (Wesche et al. 2012, Kucharski 2015). Many activities are being undertaken on their restitution, mostly in western countries of the EU due to the disappearance of those natural sites (Hölzel and Otte 2003, Klimkowska 
et al. 2010, Metsoja et at. 2012, Joyce 2014). Consequently, these meadows are of high conservation value and protected by the Habitat Directive (92/43/EEC, habitat type 6440: Alluvial meadows of river valleys of the Cnidion dubii).

The studies and works regarding the restoration of Cnidion dubii meadows resulted from the regulation the majority of big river as well of their scarcity and diminishing of those sites (Šeffer et at. 2008). Cnidion dubii meadows are located in fertile alluvial regions along the central and lower valley sections of the great rivers (Załuski 1995, 2012). Regular flooding once or twice a year and drying between floods make them play important function in the preservation of water, soils, biodiversity and landscapes. The representative species of those communities are Cnidium dubium, Allium angulosum, Sanguisorba officinalis, Gratiola officinalis, Scutellaria hastifolia and Viola stagnina. Their occurence is also bound with extensive agricultural management (cutting 1-2 times in the year). Lack of such management is often listed as a main reason of their low status of preservation (Jermaczek-Sitak 2011, Załuski 2012). In Poland, most often until now the studies of actions are implementing in the scope restoration of xerothermic meadows (Barańska 2014) and fen habitats (Klimkowska et al. 2010) or removing of invasive plants, primarily Solidago sp. (Szymura and Szymura 2014, Szymura et al. 2016, Świerszcz et al. 2017).

The Warsaw City Property Management have undertaken the realisation of the project titled "The restitution of the flooded meadows on Warsaw crosssection of Natura 2000 site Middle Vis- tula Valley - PLB 140004". Project was financed in the framework of Operation Program PL02 "Protection of biodiversity and ecosystems" 2009-2014. The restitution of half-open, partially wooded landscape with the significant share of species-rich meadows on flooded sites of Vistula river interbank was the aim of the project. Undertaken works in 2014-2015 concerned limitation growth of the invasive alien species (Solidago canadensis, S. gigantea and Acer negundo) and the introduction of the species characteristic for Cnidion dubii meadows.

Aim of the work was determination the possibility of restoration and improvement of species composition of meadows plant communities in river valleys.

\section{MATERIAL AND METHODS}

The studies area is located in the Vistula river interbank at Białołęka (geographical coordinates: $52^{\circ} 29^{\prime} \mathrm{N} ; 20^{\circ} 96^{\prime} \mathrm{E}$ ). It is being flooded at high water states. The last inundation took place in 2010. The soil is averagely coherent with grain size distribution of the silt sand originated from the loam. That terrain was used agriculturally as source of fodder for cattle and horse till the construction of the Tarchomin house settlement in 1979. The storing of the construction materials and abandonment of mowing and grazing caused the succession of trees, shrubs including especially Acer negundo, Salix sp. and Populus alba and massive growth of Solidago sp. and Erigeron annuus. Now, the upper $0-20 \mathrm{~cm}$ layer of terrain is covered by mixture of soil and building debris.

In the framework of the site preparation for field experiment establishment 
a few trees and two clumps of $A$. negun$d o$ below 10 years old were cut and rest plants was low mown. The experiment was established as a randomized complete block with six replications. The area of individual block was $120 \mathrm{~m}^{2}$ $(10 \times 12 \mathrm{~m})$.

Seeding material for restoration was taken from well preserved natural Cnidion dubii meadows in the neighborhood of Warsaw (Lower Pilica Valley - PLH 140016, 51 ${ }^{\circ} 51^{\prime} \mathrm{N} ; 21^{\circ} 15^{\prime} \mathrm{E}$ and $\left.51^{\circ} 50^{\prime} \mathrm{N} ; 21^{\circ} 17^{\prime} \mathrm{E}\right)$. Seeding material was harvested in the end of September 2014, dried under roof, breaking up, and cleaned from bigger parts of steams. Such prepared seeding material generally contained 26 native species including characteristic species for Cnidion dubii meadows (Cnidium dubium, Allium angulosum, Sanguisorba officinalis, Galium boreale), Arrhenatherion meadows (Achillea millefolium, Plantago lanceolata) and dry meadows (Artemisia campestris, Eryngium planum, Hypericum perforatum, Potentilla erecta, Verbascum thapsus). Crucial elements of the experiment were methods of seedbed preparation and plots treatments after seeding. Three methods of seedbed preparation were checked: low cutting of vegetation; ploughing, depth about $20 \mathrm{~cm}$ and rototilling without surface leveling; removal the sward and topsoil $(30 \mathrm{~cm}$ layer). On each variant of seedbed preparation two ways of area treatment after sowing: rolling; rolling plus dispersing thin layer of rye straw. Control variant for assessment of soil's seeds bank were unseeded areas.

In the blocks the sequence of the belts with various seedbed preparations, and the ways of sowing in split plot arrangement were drawn.

The seeds were dispersed by hand on prepared areas and rolled on with light roller on 25 October 2014. The seeding rate was $10 \mathrm{~g} \cdot \mathrm{m}^{-2}$ of the seeding material like was recommended by Kirmer et al. (2012). In 2015 for limitation of Solidago sp. competiveness vegetation was cut before its flowering at the height of $25 \mathrm{~cm}$. In subsequent years the mowing was done once, in autumn.

The weather conditions in the study period were not convenient for meadow establishment (Table 1). Summer (VI-VIII) of 2015 was extremely dry, especially August. The value of hydrothermal index for growing season, calculated as the quotient of total precipitation to the sum of temperature (Vinczeffy 1984),

TABLE 1. Temperature and precipitation in growing seasons 2015 and 2016 at meteorological station Ursynów - Warsaw

\begin{tabular}{|c|c|c|c|c|c|c|c|}
\hline \multirow{2}{*}{ Year } & \multicolumn{6}{|c|}{ Month } & \multirow{2}{*}{$\begin{array}{c}\text { Growing season } \\
\text { IV-IX }\end{array}$} \\
\hline & IV & $\mathrm{V}$ & VI & VII & VIII & IX & \\
\hline \multicolumn{8}{|c|}{ Sum of precipitation $(\mathrm{mm})$} \\
\hline 2015 & 31.4 & 57.7 & 37.5 & 66.2 & 11.3 & 73.1 & 277.2 \\
\hline 2016 & 34.2 & 23.3 & 56.9 & 116.5 & 71.7 & 9.8 & 312.4 \\
\hline \multicolumn{8}{|c|}{ Mean temperature $\left({ }^{\circ} \mathrm{C}\right)$} \\
\hline 2015 & 9.1 & 13.7 & 18.1 & 20.5 & 23.0 & 15.6 & 16.7 \\
\hline 2016 & 10.0 & 16.3 & 19.8 & 20.3 & 19.3 & 16.5 & 17.0 \\
\hline
\end{tabular}


was very low $\left(0.091 \mathrm{~mm} \cdot{ }^{\circ} \mathrm{C}^{-1}\right)$. Summer of 2016 was not such dry as 2015 , but precipitation in May and especially in September was very low. For growing season of 2016 the value of hydrothermal index was $0.100 \mathrm{~mm} \cdot{ }^{\circ} \mathrm{C}^{-1}$. With exception of the July, in which on $1{ }^{\circ} \mathrm{C}$ dropped $0.185 \mathrm{~mm}$ of rain, the rest of the growing season were very dry.

In the framework of the study the initial growth and development of the sown plant species and restriction the invasive species share in sward were measured. The measurement of plants growth and development were performed every month during vegetation period 2015 on $1 \mathrm{~m}^{2}$ area plots, each investigated variant in six replication. The total number of sown species was registered and the quantity of species population was expressed in point scale 1-6, where: 6 - number of occurrences of the species on all plots, and 1 - the occurrence on one plot. Every time the height of the introduced plant species was measured (in three replications on plot) and their development phase was determined. The abundance of population was determined in point scale $0-5$ on the base of their occurrence in sward, where: 0 - lack of plants, 1 - single, 2 - group, 3 - pretty numerous, 4 - numerous, 5 - very numerous.

The botanical composition of the sward was determined by noting the occurring species and the percentage of invasive and dominant ones. The extent of $A$. negundo population in 2015 was determined by counting the number of young plants. The condition of sward an assessment of ground cover with plants in the spring 2017 was done on the entire area of particular tested variant. The obtained results of plants height and occurrence values were analyzed statistically by use the variance analyze (ANOVA). The verification of the difference significance was based on Tukey's test on the level of confidence 0.05 .

\section{RESULTS AND DISCUSSION}

The studies over Cnidion dubii meadows in Poland has concerned mainly the status of their preservation (Jermaczek-Sitak 2011, Trąba and Wolański 2012, Załuski 2012, Kazuń 2014). Foreign studies show that regaining of typical meadow communities very often requires the introduction of representative species so-called target species (Hedberg and Kotowski 2010, Hölzel et al. 2012, Schmiede et al. 2012, Schmiede et al. 2013). Seedlings establishment and initial growth are the most critical stages in restitution practice. The most species require specific environmental conditions for these processes and these factors are decisive for subsequent seedlings establishment (Ludewig et al. 2014).

The initial growth and development of the majority of sown species in this experiment from the spring to the midsummer were slow. The differences in the height of the introduced plants and the dominant species in the sward, especially Solidago sp., were huge (Table 2).

Competition abilities of introduced species for light, nutrients, space and development on the plots sown after only vegetation mowing and soil cultivation (ploughing and rototilling) were significantly lower than after topsoil removal. In the middle of July 2015 the height of plants representative for Cnidion dubii meadows ranged approximately from 3 to $12 \mathrm{~cm}$. They grew the fastest on the 
TABLE 2. The height $(\mathrm{cm})$ of the most frequently occurring introduced species on the background of Solidago sp. and Acer negundo heights in July 2015 in dependence on the method of seedbed preparation and the way of seeds placement

\begin{tabular}{|c|c|c|c|c|c|c|c|}
\hline \multirow{3}{*}{ Species } & \multicolumn{2}{|c|}{ Cutting of sward } & \multicolumn{2}{|c|}{$\begin{array}{l}\text { Ploughing and } \\
\text { rototilling }\end{array}$} & \multicolumn{2}{|c|}{ Removed topsoil } & \multirow{3}{*}{$\mathrm{LSD}_{0.05}$} \\
\hline & \multicolumn{6}{|c|}{ straw mulching } & \\
\hline & yes & no & yes & no & yes & no & \\
\hline Solidago sp. & 53.8 & 43.7 & 57.7 & 51.0 & 21.5 & 14.7 & 16.4 \\
\hline Acer negundo & 11.6 & 10.9 & 14.3 & 12.7 & 9.6 & 9.5 & 4.5 \\
\hline \multicolumn{8}{|c|}{ Cnidion dubii meadows } \\
\hline Allium angulosum & 11.2 & 10.0 & 12.0 & 10.9 & 8.5 & 7.9 & 3.8 \\
\hline Cnidium dubium & 6.3 & 4.7 & 3.7 & 5.6 & 2.8 & 3.0 & 3.7 \\
\hline Galium boreale & 8.3 & 5.5 & 4.2 & 7.0 & 5.1 & 2.8 & 3.4 \\
\hline Sanguisorba officinalis & 8.2 & 4.8 & 7.7 & 5.1 & 6.0 & 5.1 & 5.4 \\
\hline \multicolumn{8}{|c|}{ Arrhenatherion meadows } \\
\hline Achillea millefolium & 18.0 & 11.7 & 11.1 & 8.2 & 8.3 & 7.9 & 3.9 \\
\hline Plantago lanceolata & 18.0 & 16.3 & 14.0 & 19.0 & 14.7 & 10.7 & 5.4 \\
\hline \multicolumn{8}{|c|}{ Dry meadows } \\
\hline Artemisia campestris & 11.3 & 11.5 & 10.5 & 7.0 & 8.6 & 9.3 & 6.8 \\
\hline Eryngium planum & 3.0 & 4.0 & 4.0 & 4.0 & 5.5 & 3.0 & 1.8 \\
\hline Hypericum perforatum & 6.3 & 7.6 & 5.3 & 9.4 & 6.4 & 7.5 & 4.7 \\
\hline Potentilla erecta & 6.0 & 2.0 & 3.9 & 4.3 & 4.2 & 4.2 & 4.0 \\
\hline \multirow[t]{3}{*}{ Verbascum thapsus } & 12.0 & 10.0 & 20.0 & 14.5 & 5.7 & 1.5 & 4.2 \\
\hline & \multicolumn{6}{|c|}{$\mathrm{LSD}_{0.05}$} & \\
\hline & 5.6 & 6.6 & 4.0 & 6.7 & 4.9 & 3.3 & \\
\hline
\end{tabular}

treatment with mowing vegetation and mulching, but the slowest - on variant with topsoil removal, and especially without mulching. The plants of $A$. angulosum grew very well and developed also on the treatment with ploughing. Mulching has fostered the growth of $S$. officinalis and $A$. angulosum. But because of large differentiation of particular specimen the differences statistically were not proved.

The initial growth and development of introduced species of lowland hay meadows (A. millefolium, $P$. lanceolata) were significantly faster than the species of Cnidion dubii meadows and in the higher degree depended on the seedbed preparation. In the middle of July the height of these species ranged approximately from 8 to $19 \mathrm{~cm}$. The slowest, but the most rampant growth was on plots with removed topsoil and without mulching. Significantly higher plants of A. millefolium were on surface sown after vegetation mowing and mulching. Plants of $P$. lanceolata also grew well after ploughing treatment without mulching. That species, except variant with sward mowing, on the remaining plots formed generative shoots. It could be caused by better lighting of plants. 
The growth and development of dry and poor habitats species in lower grade than in the case of another ones depended on the seedbed preparation. The growth and development of $A$. campestris, $H$. perforatum, $P$. erecta and E. planum were generally similar on the investigated areas. The strongest reaction on the way of introduction showed $V$. thapsus which grew the fastest on plots after ploughing and mulching. It reached in the middle of July the height of $20 \mathrm{~cm}$. This species on treatment with vegetation mowing reached height $10-12 \mathrm{~cm}$. On plots with removed topsoil they grew much slower. Loydi et al. (2013) stated that mulching could have positive effect on germination and emergence especially during dry periods through reducing water evaporation on poor soil.

The intensity of seedbed preparation affected the species number and the frequency of their occurrence. Results of survey of species occurrence in 2015 has showed presence of 17 species from the list of 26 species in seeding material. Removing topsoil with actually growing plants' rhizomes and roots allowed for emergence and growth of 17 species of new plants, including the three species representative for Cnidion dubii meadows: A. angulosum (mean value of occurrence frequency 5.5), $S$. officinalis (5.2) and G. boreale (4.2); two for Arrhenatherion meadows: A. millefolium (5.2), P. lanceolata (4.1); and two for dry meadows: A. campestris (4.6), $H$. perforatum (4.8). The plentiful occurrence of most of those species was on plots without mulching, especially $A$. angulosum and $H$. perforatum.

On variants with ploughing and rototilling the growth of 12 introduced species were noticed, but only in the case of three of them - with frequency over 3 points, two of them were the species characteristic for Cnidion dubii meadows: S. officinalis (4.2), and C. dubium (4.0); and one - with wide ecological tolerance A. millefolium (3.2). In comparison with the variant with removed topsoil $S$. officinalis and A. millefolium showed significantly lower frequency of occurrence: 4.2 and 3.7, respectivelly. Contrarily on this variant $C$. dubium occurred most numerously. Its frequency was much higher than on variant with removed topsoil and with vegetation cutting, similarly as on treatment with removed topsoil, where it occurred with larger frequency on the surfaces without mulching. The differences were high and amounted on average $40-45 \%$.

The number of introduced species and their populations' abundance decreased and in the spring 2017 were lower at average about $1-3$ species. The majority of the sown species (14) in 2017 were found on variants with removed topsoil. On the area after soil mechanical cultivation occurrence of 10 species was found. Among the species characteristic for Cnidion dubii meadows the distinctive regress of $A$. angulosum from sward was stated. In case of $A$. angulosum in spring 2017 only single plants were noted in the sward.

In the period of the study the decreasing of population size of $S$. officinalis and $C$. dubium was stated. The highest decrease in those populations had place in treatment with mown sward. As the result the size of those species population in the spring 2017 was on low level for all variants. The size of $G$. boreale population maintained at the low and stable level. 
Among the rest of the introduced species systematic growth of $P$. lanceolata and $P$. erecta were observed. Pretty well abundance in the successive years was stated for A. millefolium and $H$. perforatum. The best conditions for A. millefolium growth has created removal of topsoil and mechanical cultivation of the seedbed bed. The plough and topsoil removal fostered development of $H$. perforatum, but with time the abundance of that species has decreased.

The share of introducing species in sward in the first year after sowing was low, most frequently below $1 \%$. In the spring 2017 their share was significant higher (the Figure). They constituted of soil coverage on sown plots from 5 to $27 \%$. The highest shares of these plants in meadow sward were on the plots with removed topsoil. Sown species constitutes $64 \% \mathrm{o}$ on variant with mulching and $42 \%$ - without mulching. The relatively high share of A. millefolium, $H$. perforatum and $P$. erecta on the plots without sowing testifies their occurrence in soil seed bank. There are characteristic species of drying habitats but not indicative species for Cnidion dubii meadows.

Summer cutting of vegetation in 2015 before Solidago sp. flowering at the height of $25 \mathrm{~cm}$ has decreased their

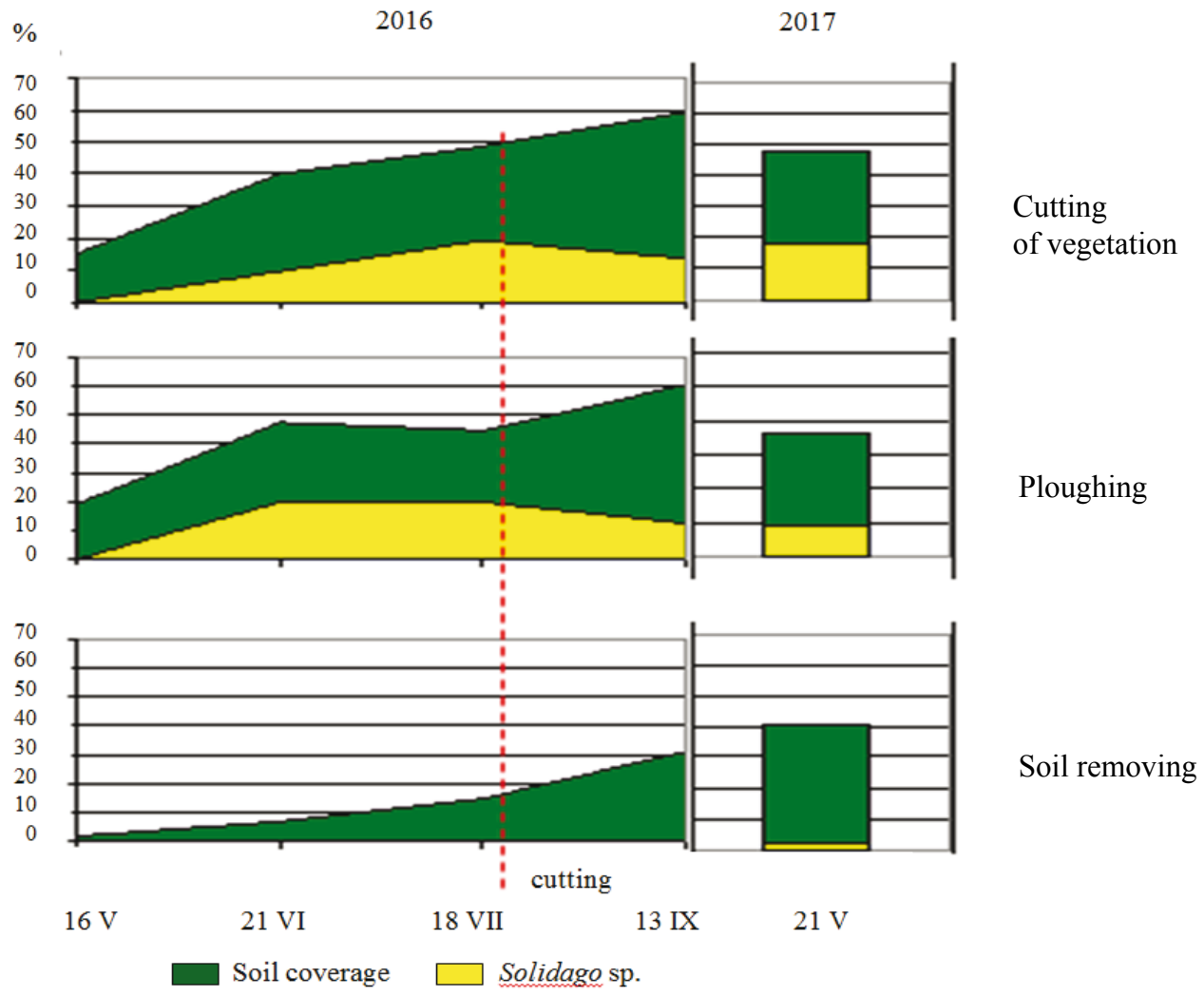

FIGURE. Soil coverage by vegetation including Solidago sp. in dependence of seedbed preparation in 2015 and 2017 
share in soil coverage, but increased the soil total coverage by plants from 26 to $46 \%$ in average (Fig.). The development of Solidago sp. was most effectively restrained by removing of surface layer of soil. Besides the introduced species in the sward the typical meadow species come into sight, especially grasses and legumes plants. Expansive species like Calamagrostis epigejos and Elymus repens also increased the share in renovated meadow sward. Kiehl et al. (2010) stated that, the long-term management of newly created grasslands has to be assured in order to suppress the spread of ruderals and woody species.

The results of introduction in the first year after sowing were promising, but in successive years that species disappeared from sward, which could be caused also by drought in August 2015 and September 2016. The difficulties with introduction and keeping target species in the meadow sward were underlined by foreign studies (Bissels et al. 2004, Hölzel and Otte 2004, Conrad and Tischew 2011). In this experiment the high effectiveness of introduction was obtained for the species of moderate wet and dry meadows, like: A. millefolium, $H$. perforatum, $P$. lanceolata and $P$. erecta. It is resulting from their broad scope for tolerance for inconvenient conditions, especially drying of the soil. The easier introduction of the species of dry sites, but on former arable fields is pointed in the study of Kiehl et al. (2006).

Studies on the biology of characteristic species of Cnidion dubii meadows may contribute to success of community's restoration (Jensen 2004, Engst et al. 2016, Janicka et al. 2016). Those species characterize themselves by slow speed of growth and development, what in the presence of fast re-growing initial topsoil' species, especially invasive ones, limits the further development of the target species. Szymura and Szymura (2014), Swierszcz (2017) stated that the presence of strongly completive, high and alien species, like Solidago sp. or A. negundo, in sward threatens the biological diversity. In the last decades more frequent penetration of invasive species, especially Solidago sp., to meadow communities is being observed not only in Poland but also in other countries of the East Central Europe (Szymura et al. 2016).

\section{CONCLUSIONS}

The intensity of seedbed preparation affected the species number and the frequency of their occurrence. Removing of topsoil layer of $30 \mathrm{~cm}$ thick with actually growing plants' rhizomes and roots allowed for emergence and growth of the three species representative for Cnidion dubii meadows, two species representative for lowland hay meadows, and five species representatives for dry meadows. Applied methods of soil preparation and used seeding material allowed to install generally of 17 meadow plant species instead of the invasive species of Solidago sp. and $A$. negundo and significantly improved the natural value of the restored site.

The development of Solidago sp. was most effectively restrained by removing of surface layer of soil. Removing of topsoil favored growth of representative for Cnidion dubii meadows species $S$. officinalis, A. angulosum and G. boreale, but $C$. dubium developed the best on plots after ploughing and rototilling. 
The number of introduced species and their populations' abundance decreased and in the third year after sowing were lower at average about 1-3 species. On variants with removed topsoil decrease of species number was lower. For species representative of Cnidion dubii meadows the distinctive regress of $A$. angulosum from sward was stated and in case of A. angulosum in 2017 only single plant individuals were noted in the sward.

Summer cutting before Solidago sp. flowering has decreased its expansion. It allowed for typical meadow species come into sight, but also for expansive species, like C. epigejos and E. repens, that gradually increased it share in sward and started to compete with the introduced species. It points on necessity of further protection - care of the introduced species by working out detailed management of the restored sites.

\section{REFERENCES}

BALLESTEROS M., PETROVIC D., VANCAUWENBERGH S., GREIBER T., KEMP J., JEN S., LI N., NIETO A. 2014: Experience gained in the application of ELD biodiversity damage. Final report for the European Commission, DG Environment. Milieu IUCN, Brussels.

BARAŃSKA K. 2014: Podręcznik najlepszych praktyk ochrony kseroterm. Centrum Koordynacji Projektów Środowiskowych, Warszawa.

BISSELS S., HÖLZEL N., DONATH T.W., OTTE A. 2004: Evaluation of restoration success in alluvial grasslands under contrasting flooding regimes. Biol. Conserv. 118, 641-650.

Birds Directive 2009: 2009/147/EC of the European Parliament and of the Council of 30 November 2009 on the conservation of wild birds. L 20/7, 1-19.

CONRAD M., TISCHEW S. 2011: Grassland restoration in practice: Do we achieve the targets? A case study from Saxony-Anhalt/Germany. Ecol. Eng. 37, 1149-1157.
Directive 2004/35/CE of the European Parliament and of the Council of 21 April 2004 on environmental liability with regard to the prevention and remedying of environmental damage. L 143/56.

ENGST K., BAASCH A., ERFMEIER A., JANDT U., MAY K., SCHMIEDE R., BRUELHEIDE H. 2016: Functional community ecology meets restoration ecology: Assessing the restoration success of alluvial floodplain meadows with functional traits. J. Appl. Ecol. 53, 751-764.

European Commission 2011: The EU Biodiversity Strategy to 2020. Publications Office of the European Union.

Habitat Directive 1992: 92/43/EEC of 21 May 1992 on the conservation of natural habitats and of wild fauna and flora. L 206/7, 1-44.

HEDBERG P., KOTOWSKI W. 2010: New nature by sowing? The current state of species introduction in grassland restoration, and the road ahead. J. Nature Conserv. 18, 304-308.

HÖLZEL N., BUISSON E., DUTOITI T. 2012: Species introduction - a major topic in vegetation restoration. Appl. Veg. Sci. 15, 161-165.

HÖLZEL N., OTTE, A. 2003: Restoration of a species-rich flood meadow by topsoil removal and diaspore transfer with plant material. Appl. Veg. Sci. 6, 131-140.

HÖLZEL N., OTTE A. 2004: Ecological significance of seed germination characteristics in flood-meadow species. Flora 199, 12-24.

JANICKA M., PAWLUŚKIEWICZ B., MAŁUSZYŃSKA E., SZYDŁOWSKA A. 2016: The estimation of some wild flowers seed material from the natural-valuable meadow habitats. Ann. Warsaw Univ. Life Sci. - SGGW, Land Reclam. 48, 329-340.

JENSEN K. 2004: Dormancy patterns, germination ecology, and seed-bank types of twenty temperate fen grassland species. Wetlands 24, 152-166.

JERMACZEK-SITAK M. 2011: Charakter i stan zachowania łąk selernicowych Cnidion w zachodniej Polsce a warunki wodne. Przeglad Przyrodniczy 22, 83-90.

JOYCE C.B. 2014: Ecological consequences and restoration potential of abandoned wet grasslands. Ecol. Eng. 66, 91-102.

KAZUŃ A. 2014: Alluvial meadows of Cnidion dubii Bal.-Tul. 1966 in the middle Oder river 
valley (Natura 2000 site "Eęgi Odrzańskie", SW Poland). Steciana 18, 49-55.

KIEHL K., THORMANN A., PFADENHAUER J. 2006: Evaluation of initial restoration measures during the restoration of calcareous grasslands on former arable fields. Restor. Ecol. 14, 148-156.

KIEHL K., KIRMER A., DONATH T.W., RASRAN L., HÖLZEL N. 2010: Species introduction in restoration projects - Evaluation of different techniques for the establishment of semi-natural grasslands in Central and Northwestern Europe. Basic Appl. Ecol. 11, 285-299 .

KIRMER A., MANN S., STOLLE M., KRAUTZER B., GRAISS W., HASLGRÜBLER P., ŠEVČIKOVA M., SCOTTON M. 2012: Techniques for the establishment of speciesrich grasslands. [In:] M. Scotton, A. Kirmer, B. Krautzer (Eds). Practical handbook for seed harvest and ecological restoration of species-rich grasslands. CLEUP, Padova, 43-58.

KLIMKOWSKA A., KOTOWSKI W., van DIGGELEN R., GROOTJANS A.P., DZIERŻA P., BRZEZIŃSKA K. 2010: Vegetation re-development after fen meadow restoration by topsoil removal and hay transfer. Restor. Ecol. 18, 924-933.

KUCHARSKI L. 2015: Vegetation in abandoned meadows in central Poland: Pilsia valley. Case study. Acta Sci. Pol. Agricultura 14, 37-47.

METSOJA J.A., NEUENKAMP L., PIHU S., VELLAK K., KALWIJ J.M., ZOBEL M. 2012: Restoration of flooded meadows in Estonia - vegetation changes and management indicators. Appl. Veg. Sci. 15, 231-244.

LOYDI A., ECKSTEIN R.L., OTTE A., DONATH T.W. 2013: Effects of litter on seedling establishment in natural and semi-natural grasslands: a meta-analysis. J. Ecol. 101, 454-464.

LUDEWIG K., ZELLE B., ECKSTEIN L., MOSNER E., OTTE A., TOBIAS W., DONATH T. 2004: Differential effects of reduced water potential on the germination of floodplain grassland species indicative of wet and dry habitats. Seed Sci. Res. 24, 49-61.

SCHMIEDE R., OTTE A., DONATH T.W. 2012: Enhancing plant biodiversity in species-poor grassland through plant material transfer - the impact of sward disturbance. Appl. Veg. Sci. 15, 290-298.
SCHMIEDE R., RUPRECHT E., ECKSTEIN R.L., OTTE A., DONATH T.W. 2013: Establishment of rare flood meadow species by plant material transfer: Experimental tests of threshold amounts and the effect of sowing position. Biol. Conserv. 159, 222-229.

ŠEFFER J., JANÁK M., ŠEFFEROVÁ-STANOVÁ V. 2008: Management of Natura 2000 habitats Alluvial meadows of river valleys of the Cnidion dubii (6440). Technical Report. European Commission 17/24.

ŚWIERSZCZ S., SZYMURA M., WOLSKI K., SZYMURA T.H. 2017: Comparison of methods for restoring meadows invaded by Solidago species. Pol. J. Environ. Stud. 26, 1251-1258.

SZYMURA M., SZYMURA T.H. 2014: Growth, phenology, and biomass allocation of alien Solidago species in central Europe. Plant Species Biol. 30, 245-256.

SZYMURA M., SZYMURA T.H., WOLSKI K. 2016: Invasive Solidago species: how large area do they occupy and what would be the cost of their removal? Pol. J. Ecol. 64, 25-34.

TRĄBA C., WOLAŃSKI P. 2012: Zróżnicownie florystyczne zbiorowisk łąkowych ze związków Molinion, Cnidion dubii i Filipendulion w Polsce - zagrożenia i ochrona. Inż. Ekol. 29, 224-235.

VINCZEFFY I. 1984: The effects of some ecological factors on grass yield. Proceedings of the $10^{\text {th }}$ General Meeting of European Grassland Federation, Ås, Norwegia, 76-79.

WESCHE K., KRAUSE B., CULMSEE H., LEUSCHNER C. 2012: Fifty years of change in Central European grassland vegetation: Large losses in species richness and animal pollinated plants. Biol. Conserv. 150, 76-85.

ZAŁUSKI T. 1995: Łąki selernicowe (związek Cnidion dubii Bal.-Tul. 1966) w Polsce. Monogr. Bot. 77, 1-142.

ZAŁUSKI T. 2012: 6440 Łąki selernicowe (Cnidion dubii). [In:] W. Mróz (Ed.). Monitoring siedlisk przyrodniczych. Przewodnik metodyczny. Part 3. GIOS, Warszawa, 3, 64-78.

Streszczenie: Restytucja tąk selernicowych na warszawskim odcinku Doliny Środkowej Wisty. Badania przeprowadzono w ramach restytucji łąk zalewowych na warszawskim odcinku ostoi Natura 2000 Dolina Środkowej Wisły. Dotyczyły one 
określenia możliwości poprawy składu gatunkowego zbiorowisk łąkowych w dolinach rzecznych poprzez ograniczenie wzrostu gatunków obcych, inwazyjnych i wprowadzenie diaspor gatunków $\mathrm{z}$ naturalnych łąk. Materiał siewny do restytucji pobrano z dobrze zachowanych łąk selernicowych położonych w Dolinie Dolnej Pilicy w okolicach Warszawy. Materiał siewny zawierał 26 gatunków naturalnych łąk, w tym gatunki reprezentatywne dla łąk selernicowych: Cnidium dubium, Allium angulosum, Sanguisorba officinalis i Galium boreale. Zastosowano trzy poziomy intensywności przygotowania podłoża: niskie koszenie roślinności; orkę na głębokość $20 \mathrm{~cm}$ i gryzowanie; usunięcie darni i górnej warstwy gleby o grubości $30 \mathrm{~cm}$. Przetestowano dwa sposoby siewu: siew $\mathrm{z}$ wałowaniem i z mulczowaniem (okrycie słomą); siew z wałowaniem, bez mulczowania. Zastosowane metody przygotowania podłoża i użyty materiał siewny pozwoliły wprowadzić 17 gatun- ków. Usunięcie wierzchniej warstwy gleby było najbardziej efektywne w ograniczeniu występowania gatunków inwazyjnych i sprzyjało wschodom oraz początkowemu wzrostowi Sanguisorba officinalis, Allium angulosum i Galium boreale. Orka i gryzowanie efektywnie ograniczyły występowanie Acer negundo i sprzyjały rozwojowi Cnidium dubium.

\section{MS received November 2017}

\author{
Authors' address: \\ Bogumiła Pawluśkiewicz \\ Katedra Kształtowania Środowiska \\ Wydział Budownictwa i Inżynierii Środowiska \\ SGGW \\ ul. Nowoursynowska 166, 02-787 Warszawa \\ Poland \\ e-mail: bogumila_pawluskiewicz@sggw.pl
}

